\title{
PREPARTUM ADMINISTRATION OF VITAMIN E AND SELENIUM INJECTION AND ITS ABIDING EFFECT ON CALF WEIGHT, PLACENTAL WEIGHT AND EXPULSION TIME OF FETAL MEMBRANE IN SURTI BUFFALOES
}

\author{
L. C. Modi", C. T. KhasatiYa, M. D. PATEL ${ }^{1}$ \\ K. K. TYAGI ${ }^{2}$ AND F. MODI ${ }^{3}$ \\ Department of Veterinary Gynaecology and Obstetrics \\ College of Veterinary Science and Animal Husbandry \\ Navsari Agricultural University, Navsari, Gujarat - 396 450, India
}

\begin{abstract}
A study was conducted on twenty (20) Surti buffaloes during their transient period categorized into two groups; treatment $(n=10)$ and control $(n=10)$ groups. In treatment group of animals to which $10 \mathrm{~mL}$ DL- $\alpha$ tocopheryl acetate I.P. equivalent to tocopherol (vitamin E) base $-50 \mathrm{mg}$, sodium selenite U.S.P.

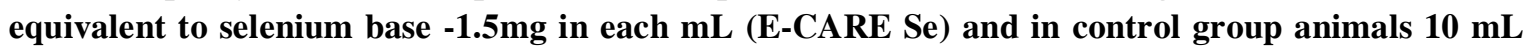
normal saline injected $\mathrm{i} / \mathrm{m}$ on $60^{\text {th }}, 4^{\text {th }}, 30^{\text {th }}$ and $15^{\text {th }}$ day before expected date of parturition and after parturition on $15^{\text {th }}$ and $30^{\text {th }}$ day. The mean expulsion time of fetal membranes in the treatment group was found to be significantly shorter than that of control group. The mean placental weight in the treatment group was found to be non-significantly lower than that of control group. The calf weight in the treatment and control group did not differ significantly.
\end{abstract}

Key words: Buffaloes, Calf weight, Placental studies, Prepartum, Selenium, Vitamin E

The transition or periparturient period, from 3 weeks before to 3 weeks after parturition, is a stressful time for dairy cows (Drackley, 1999). During gestation oxidative stress plays a role in the initiation of pre-term labor (Pressman et al., 2003) and during normal parturition (Fainaru et al., 2002) assuring ovulation, ovarian steroidogenesis, oocyte maturation, blastocyst formation, luteolysis and luteal maintenance in pregnancy (Sugino et al., 2000). Vitamin E is an important

*Corresponding Author

${ }^{1}$ Department of Veterinary Medicine, College of Veterinary Sci. \& A.H., Navsari Agricultural University, Navsari, Gujarat

${ }^{2}$ Livestock Research Station, Navsari Agricultural University, Navsari, Gujarat

${ }^{3}$ Department of Veterinary Pharmacology \& Toxicology, College of Veterinary Sci. \& A.H., Navsari Agricultural University, Navsari, Gujarat 
antioxidant that has been shown to play an important role in immuno responsiveness and health in dairy cows (Weiss and Spears, 2006). In vitamin $E$ and selenium deficiency condition, free radicals accumulate and not only damage cell membranes, but also disrupt several processes linked to the synthesis of steroids (Segerson and Libby, 1982), prostaglandins (Harrison and Conrad, 1984), sperm motility and the development of the embryo (Goff, 1999). It is not surprising therefore that negative impacts of vitamin $\mathrm{E}$ and selenium deficiencies have been observed on various components of the reproductive events, including ovulation rate (Goto et al., 1992), uterine motility, sperm motility and transport (Robinson, 1996), conception rate and post-partum activities (Jie et al., 2004), fetal membrane expulsion (Talavera et al., 1985), embryo survival, milk production and post natal growth (Garcia et al., 2001). Hence, present study was planned to observe the effect of periparturient injection of vitamin $\mathrm{E}$ and selenium on calf weight, placental weight and fetal membrane expulsion time in Surti buffaloes.

\section{MATERIALS AND METHODS}

The present study was performed as a part of PG research work, which was approved by Director of Research, Navsari Agricultural University, Navsari, Gujarat. The study was conducted between May 2014 and April 2015 at Livestock Research Station (LRS), Navsari Agricultural University (NAU), Navsari, Gujarat, India. For the investigation, twenty (20) Surti buffaloes during their transient period i.e. two month before their expected date of parturition to two month after parturition selected from LRS, NAU, Navsari and dividing into two groups; treatment $(\mathrm{n}=10)$ and control $(n=10)$ groups. In treatment group of animals to which $10 \mathrm{~mL} \mathrm{DL- \alpha}$ tocopheryl acetate I.P. equivalent to tocopherol (vitamin E) base $-50 \mathrm{mg}$, sodium selenite U.S.P. equivalent to selenium base $-1.5 \mathrm{mg}$ in each $\mathrm{mL}$ (E-CARE Se) and in control group animals $10 \mathrm{~mL}$ normal saline injected $\mathrm{i} / \mathrm{m}$ on $60^{\text {th }}, 45^{\text {th }}, 30^{\text {th }}$ and $15^{\text {th }}$ day before expected date of parturition (prepartum) and after parturition on $15^{\text {th }}$ and $30^{\text {th }}$ day. The time taken for the expulsion of fetal membrane in each buffalo following a complete parturition was recorded in hours. Each of entire expelled placenta was carefully collected and weighted in kilogram $(\mathrm{Kg})$ with the help of electronic weighing balance. After the parturition, the weight of new born calf was carried out in kilogram $(\mathrm{Kg})$ with the help of weighing machine. The tests of significance for treatment vs. control groups were made by Standard Student's paired ' $t$ ' test.

\section{RESULTS}

The mean expulsion time of fetal membranes in the treatment group was found to be significantly $(\mathrm{P}<0.01)$ shorter ( $3.220 \pm 0.199$; range 2.30 to $4.45 \mathrm{hrs}$ ) than that of control group $(4.370 \pm 0.104$; range 2.55 to $5.10 \mathrm{hrs}$ ) with the overall mean of $3.795 \pm 0.171$ hrs. Further, overall mean times for expulsion of placenta did not differ significantly $(\mathrm{p}>0.05)$ between birth of male (3.81 $\pm 0.27 \mathrm{hrs})$ and female (4.08 \pm 0.39 hrs) calves (Table 1 ). 
Prepartum administration of vit-E, selenium inj and its effect in Surti buffaloes

Table 1. Expulsion of fetal membranes, placental weight and calf weight in antioxidant treated and control group of Surti buffaloes (Mean $\pm \mathrm{SE}$ )

\begin{tabular}{lccc}
\hline \multicolumn{1}{c}{ Parameters } & $\begin{array}{c}\text { Treatment group } \\
(\mathbf{n = 1 0})\end{array}$ & $\begin{array}{c}\text { Control group } \\
(\mathbf{n = 1 0})\end{array}$ & 't'- value \\
\hline Expulsion of fetal membranes $(\mathrm{hrs})$ & $03.220 \pm 0.199$ & $04.370 \pm 0.104$ & $5.119^{* *}$ \\
Placental weight $(\mathrm{Kg})$ & $03.373 \pm 0.100$ & $03.442 \pm 0.052$ & 0.611 \\
Calf weight $(\mathrm{Kg})$ & $20.700 \pm 1.065$ & $20.450 \pm 1.071$ & 0.166 \\
\hline
\end{tabular}

$* * \mathrm{p}<0.01$ between treatment and control group

The mean placental weight in the treatment group was found to be non-significantly lower than that of control group $(3.373 \pm$ 0.100 ; range 3.10 to $4.10 \mathrm{Kg}$ vs. $3.442 \pm$ 0.052 ; range 3.20 to $3.83 \mathrm{Kg}$ ) with an overall of $3.408 \pm 0.056 \mathrm{Kg}$ in Surti buffaloes (Table 1).

The mean calf weight in the treatment group was found to be $20.70 \pm 1.07$ (range from 16 to 27$) \mathrm{Kg}$ and that of control group 20.45 \pm 1.07 (range from 13.50 to 24$) \mathrm{Kg}$ with an overall mean of $20.58 \pm 0.74 \mathrm{Kg}$. The calf weight in the treatment and control group did not differ significantly (Table 1).

\section{DISCUSSION}

The mean expulsion time of fetal membranes in the treatment (vitamin $\mathrm{E}$ and selenium) group in the present study was found significantly $(\mathrm{p}<0.01)$ earlier as compared to control group $(3.220 \pm 0.199$ vs. $4.370 \pm 0.104 \mathrm{hrs})$. This observation agreed with Deori et al. (2014) in Indian yaks; and Panda et al. (2006) and Amer and Badr (2008) in buffaloes, they all found significantly $(\mathrm{p}<0.05)$ shorter mean expulsion time of fetal membranes in the vitE selenium treatment group as compared to control group of animals. The mean placental expulsion time in the present study was found shorter than the normal physiological range of 6.0 to $8.0 \mathrm{hrs}$.

According to Youssef et al. (1985), pregnant animals are more susceptible to selenium deficiency than non-pregnant animals, which increase the incidence of prepartum and postpartum reproductive disorders. The shorter placental expulsion period in the vitamin E-selenium treated animals may have been due to improved uterine muscular function (Youssef et al., 1985). The mechanism by which selenium enhances expulsion of the fetal membranes after parturition is not well-defined but could involve effects on steroidogenesis (Staats et al., 1988) or prostaglandin synthesis (Marshall et al., 1987). Furthermore, vitamin E and selenium might act by promoting function of neutrophils, as the cows which experienced retained fetal membranes had reduced neutrophil function postpartum. Further, selenium 
could influence contractility of the uterus after parturition/during expulsion of the fetal membranes because injection of selenium or vitamin $\mathrm{E}$ and selenium was shown to increase contractile activity of the ovine uterus.

Singh et al. (1994) reported higher mean weight of placenta as $3.83 \pm 0.19 \mathrm{Kg}$ in buffaloes, whereas comparatively lower weight than the present one has been documented by Pugashetti et al. (2002) in HF X Deoni cows; and Murugeppa et al. (1998) in Surti buffaloes. Moreover, Pugashetti et al. (2002) in HF X Deoni cows with male and female calves reported 3.14 $\pm 0.12 \mathrm{Kg}$ vs. $3.00 \pm 0.6 \mathrm{Kg}$ and $2.82 \mathrm{Kg}$ vs. $2.69 \mathrm{Kg}$ weight of placenta, respectively, which were also found comparatively lower than the present findings.

The higher and lower weight of placenta as compared to present findings reported by different research workers might be attributed to breed, species, gestation length and parity of those animals in addition to birth of male or female calves.

These results in terms of calf weight in treatment and control group were in line with various research workers, who compared vitamin $\mathrm{E}$ and selenium with various dose rate, regiment and route and reported non-significantly ( $\mathrm{p}>0.05)$ higher birth weight of calves in treatment group as compared to control group of cattle (Moeini et al., 2009) and buffaloes (Khan et al., 2015).
Moreover, non-significant difference in birth weight of calf reported in vitamin $\mathrm{E}$ and selenium injection group, vitamin $\mathrm{E}$ and selenium plus oral vitamin $E$ supplementation group and only oral vitamin E supplementation group of Holstein cows by Kafilzadeh et al. (2014) could be because of the sufficiency of vitamin $E$ and selenium level in all experimental groups. The overall nonsignificant ( $p>0.05)$ effect of vitamin $E$ and selenium on calf birth weight suggested that vitamin $\mathrm{E}$ and selenium treatment did not affect the calf performance. In contrast to this study, Panda et al. (2006) observed significantly $(\mathrm{p}<0.05)$ higher average birth weight of calves $(37.17 \mathrm{Kg}$ vs. $33.16 \mathrm{Kg}$ ) in $\alpha$-tocopheryl acetate supplemented than control group of buffaloes.

So it can be concluded that differences among placental weight and calf weight were not observed between treatment and control groups, but the time of expulsion of fetal membranes was significantly shorter in peripartum vitamin $\mathrm{E}$ and selenium treated group as compared to control group of buffaloes.

Conflict of interest: Authors declare that there is no conflict of interest regarding the present research work.

\section{ACKNOWLEDGMENTS}

The authors are highly thankful to the Dean, Vanbandhu College of Veterinary Science and A.H. for financial assistance and research facilities to conduct this 
experiment. The authors also thank Research Scientist, Livestock Research

\section{REFERENCES}

Amer HA and Badr AM, 2008. Influence of antepartum administration of immunopotentiators on reproductive efficacy of buffalo and viability of their newborn. Veterinaria Italiana, 44 (2): 373-382

Deori S, Bam J and Paul V, 2014. Efficacy of prepartal vitamin $E$ and selenium administration on fertility in Indian yaks (Poephagus Grunniens). Vet Arhiv, 84(5): 513-519

Drackley JK, 1999. Biology of dairy cows during the transition period: the final frontier? J Dairy Sci, 82(11): 2259-2273

Fainaru O, Almog B, Pinchuk I, Kupferminc MJ and Lichtenberg D et al., 2002. Active labour is associated with increased oxidisibility of serum lipids ex vivo. BJOG, 109(8): 938-941

Garcia G, Cavellaro L, Broussalis A, Ferraro G and Martino V, 2001. Phytother Res, 1995, 9, 251 (cited from Erik De Clercq. J Pharmacol Exp Therap, 297: 1)

Goff JP, 1999. Dry cow nutrition and metabolic disease in parturient cows. Proceeding Western Canadian Dairy Seminar Red Deer, pp177-202

Goto Y, Noda Y, Narimoto K, Umaoka Y and Mori T, 1992. Oxidative stress on mouse embryo development in vitro. Free Radical Biol Med, 13: 47-53
Station, NAU for the availability of experimental animals.

Harrison JH and Conrad HR, 1984. Effect of selenium intake on selenium utilization by the non-lactating dairy cow. J Dairy Sci, 67: 219-223

Jie JL, Douglas SJ, Drago R and Bruce DR, 2004. Contemporary Drug Synthesis. John Wile \& Sons Inc Hoboken, New Jersey, pp 397

Kafilzadeh F, Kheirmanesh H, Targhibi MR, Maleki E and Shabankareh HK et al., 2014. Comparing the effect of oral supplementation of vitamin $\mathrm{E}$, injective vitamin $\mathrm{E}$ and selenium or both during late pregnancy on production and reproductive performance and immune function of dairy cows and calves. Sci world J, Article ID 165841, 5 pages http:/ /dx.doi.org/ 10.1155/2014/165841

Khan HM, Mohanty TK, Bhakat M, Gupta AK and Mondal G, 2015. Effect of vitamin E and mineral supplementation during peripartum period on BCS, body weight and calf performance in Murrah buffaloes. Buffalo Bull, 34(1): 79-85

Marshall PJ, Kulmacz RJ and Lands WEM, 1987. Constraints on prostaglandin biosynthesis in tissues. J Biol Chem, 262: 3510-3517

Moeini MM, Karami H and Mikaeili E, 2009. Effect of selenium and vitamin $\mathrm{E}$ supplementation during the late 
pregnancy on reproductive indices and milk production in heifers. Anim Reprod Sci, 114: 109-114

Murugeppa A, Apaannavar MM, Patil NA and Honnappogol SS, 1998. Study on placental membrane and its effect on subsequent fertility in Surti buffaloes. Buffalo Bull, 17 (2): 35-36

Panda N, Kaur H and Mohanty TK, 2006. Reproductive performance of dairy buffaloes supplemented with varying levels of vitamin E. Asian-Aust J Anim Sci, 19(1): 19-25

Pressman EK, Cavanaugh JL, Mingione M, Norkus EP and Woods JR, 2003. Effects of maternal antioxidant supplementation on maternal and fetal antioxidant levels: a randomized, double-blind study. Am J Obstet Gynecol, 189(6): 1720-1725

Pugashetti B, Shivakumar MC, Hosamani SV and Kulkarni VS, 2002. Studies on the placental characteristic in HF $\times$ Doeni cows. Karnataka J Agric Sci, 15: 559-561

Robinson JJ, 1996. Nutrition and reproduction. Anim Reprod Sci, 42: 25-34

Segerson EC and Libby DW, 1982. Ova fertilization and sperm number per fertilized ovum for selenium and vitamin E treated Charolais cattle. Theriogenology, 17: 333-341
Singh R, Khar SK and Chander S, 1994. Parturition in buffaloes. Indian J Anim Sci, 64(10): 1028-1033

Staats DA, Lohr DP and Colby HD, 1988. Effects of tocopherol depletion on the regional differences in adrenal microsomal lipid peroxidation and steroid metabolism. Endocrinol, 123: 975-980

Sugino N, Takiguchi S, Kashida S, Karube A and Nakamura Y et al., 2000. Superoxide dismutase expression in the human corpus luteum during the menstrual cycle and in early pregnancy. Mol Hum Reprod, 6(1): 19-25

Talavera E, Park CS and Williams GL, 1985. Relationships among dietary lipid intake, serum cholesterol and ovarian function in Holstein heifers. J Anim Sci, 60: 1045

Weiss WP and Spears JW, 2006. Vitamin and trace mineral effects on immune function of ruminants. In: Sejrsen K, Hvelplund T, Nielsen MO (Eds.), Ruminant Physiology. Wageningen Academic Publishers, Utrecht, The Netherlands, pp473-496

Youssef RH, Awad YL and Mikhail MF, 1985. Effect of prepartum selenium treatment on retained placenta in buffaloes and on their subsequent fertility. Egyptian J Vet Sci, 22(10): 65-71 